\title{
Metal-ion tolerance in Escherichia coli: analysis of transcriptional profiles by gene-array technology
}

\author{
Kathryn R. Brocklehurst and Andrew P. Morby \\ Author for correspondence: Andrew P. Morby. Tel: +44 2920 874128. Fax: +44 2920874116. \\ e-mail:morby@cf.ac.uk
}

School of Biosciences, Cardiff University, Museum Avenue, Cardiff CF10 3US, UK

\begin{abstract}
Escherichia coli was adapted to grow in medium containing substantially elevated concentrations of either $\mathrm{Zn}$ (II), $\mathrm{Cd}(\mathrm{II}), \mathrm{Co}$ (II) or $\mathrm{Ni}$ (II). Whole-genome transcriptional profiles were generated from adapted strains and analysed for significant alteration in transcript abundance with reference to a wild-type strain. Similar alterations in specific message levels were observed for strains adapted to the four metal ions. One unexpected trend was the increase in transcript level of genes involved in transposition of IS elements, particularly insA. Subsequent expression of insA-7 from a heterologous promoter in E. coli conferred tolerance to $\mathrm{Zn}$ (II).
\end{abstract}

Keywords: Escherichia coli, metal ion, adaptation, gene array, ins A

\section{INTRODUCTION}

Many mechanisms solely responsible for specific metalion resistance in prokaryotes have been described at the molecular level (recently reviewed by Nies, 1999; Xu et al., 1998). The effect of metal-ion stress on microbial cells/communities has been investigated and suggests that individual strains adapt to elevated metal-ion concentrations; however, no analysis of the resultant strains was initiated at the molecular level (reviewed by Giller et al., 1998; Kelly et al., 1999). Limited genetic analysis has been performed for a Cd(II)-tolerant strain of Synechococcus PCC 7942 that demonstrated an increase in the chromosomal gene copy number of $s m t A$, which encodes a prokaryotic metallothionein capable of binding $\mathrm{Cd}(\mathrm{II})$ and other divalent metal ions (Gupta et al., 1992). In addition, the regulatory gene $s m t B$ was shown to carry a deletion rendering the smt repressor protein non-functional (Gupta et al., 1993). The molecular bases for the increase in $\mathrm{Cd}(\mathrm{II})$ tolerance in Synechococcus are almost certainly more extensive than the amplification/deletion within the smt locus, although at the time of the original experiments further characterization of other chromosomal alterations was not possible. As far as we are aware, genomic analysis of metal tolerance in bacterial cells has not been undertaken.

The recent advent of array technology has allowed the global study of all 4255 genes in Escherichia coli. This work details the investigation of metal-ion tolerance in E. coli adapted to $\mathrm{Zn}(\mathrm{II}), \mathrm{Cd}(\mathrm{II}), \mathrm{Co}(\mathrm{II})$ and $\mathrm{Ni}(\mathrm{II})$, and the results demonstrate that the transcript abundance of a range of genes was altered in tolerant strains. In particular, the transcript level of ins $A$ was increased in $\mathrm{Zn}(\mathrm{II})-, \mathrm{Cd}(\mathrm{II})$ - and $\mathrm{Co}(\mathrm{II})$-adapted strains. The subsequent expression of ins A-7 from a heterologous promoter conferred $\mathrm{Zn}(\mathrm{II})$ tolerance on E. coli.

\section{METHODS}

Bacterial strains and plasmids. All experiments were carried out using as host Escherichia coli TG1 (described in Sambrook et al., 1989) [K12, lac-pro supE thi hsdD5 $\left(\mathrm{F}^{\prime}\right.$ traD36 pro $A^{+} B^{+}$ lacl $^{\mathrm{a}}$ lacZ M15)] or E. coli TG2 (described in Sambrook et al., 1989) (which is E. coli TG1 carrying the $\operatorname{rec} A:: \operatorname{Tn} 10 \mathrm{mu}-$ tation). pBAD24 (Guzman et al., 1995) was used for insA-7 expression. All strains were cultured in Luria-Bertani medium and antibiotics were added to the medium at standard concentrations unless otherwise specified (Sambrook et al., 1989).

Adaptation of $\boldsymbol{E}$. coli TG1 to metal-ion tolerance. A $10 \mathrm{ml}$ volume of LB medium was inoculated with $150 \mu \mathrm{l}$ of an overnight culture of E. coli TG1 and grown with shaking for $1.5 \mathrm{~h}$, before $200 \mu \mathrm{l}$ aliquots were transferred into a 96-well plate containing an increasing range of metal-ion concentrations of $\mathrm{Zn}(\mathrm{II})\left(\mathrm{ZnSO}_{4}\right), \mathrm{Cd}(\mathrm{II})\left(\mathrm{CdSO}_{4}\right), \mathrm{Co}(\mathrm{II})\left(\mathrm{CoSO}_{4}\right)$ and $\mathrm{Ni}(\mathrm{II})\left(\mathrm{NiSO}_{4}\right)$. The plates were incubated at $37^{\circ} \mathrm{C}$ for 24-48 h with shaking (Camlab Microtherm; 500 r.p.m.) and the $\mathrm{OD}_{600}$ of cell cultures was measured (Molecular Devices Thermo max microplate reader). A $150 \mu \mathrm{l}$ volume was taken from the well containing the highest concentration of each individual metal ion where the $\mathrm{OD}_{600}$ was $\geqslant 0 \cdot 100$, and this was used to inoculate $10 \mathrm{ml} \mathrm{LB}$ medium for further adaptive incubation. This stepwise adaptation generated strains with 
increased tolerance to $\mathrm{Zn}(\mathrm{II})$ (strain EZn), Cd(II) (strain ECd), $\mathrm{Co}(\mathrm{II})$ (strain ECo) and $\mathrm{Ni}(\mathrm{II})$ (strain ENi). Adaptation was concluded when cultures reached a stable tolerance maximum over two serial culture steps. The resultant cultures were either diluted $50 \%(\mathrm{v} / \mathrm{v})$ with glycerol for storage or used for the isolation of RNA.

Measurement of metal-ion tolerance (MICs). A $30 \mathrm{ml}$ volume of LB medium was inoculated with the individual strains of $E$. coli TG1, EZn, ECd, ECo and ENi, and grown with shaking for $1 \mathrm{~h}$ at $37^{\circ} \mathrm{C}$. A $200 \mu \mathrm{l}$ sample of each culture was transferred into separate wells of a microtitre plate which contained increasing ranges of metal-ion concentrations, and incubated at $37^{\circ} \mathrm{C}$ for $24 \mathrm{~h}$ with shaking (Camlab Microtherm; 500 r.p.m.). The $\mathrm{OD}_{600}$ of cell cultures was then measured (Molecular Devices Thermo max microplate reader). MICs for each strain were measured for the four metal ions $\mathrm{Zn}(\mathrm{II}), \mathrm{Cd}(\mathrm{II}), \mathrm{Co}(\mathrm{II})$ and $\mathrm{Ni}(\mathrm{II})$. In some cases it was impossible to accurately determine an MIC as the strains grew in medium in which the given metal ion was at the limit of solubility.

Whole-genome transcriptional analysis. E. coli Panorama arrays were used throughout this work (Sigma-Genosys). Metal-ion-tolerant E. coli strains were grown to stationary phase in LB containing the maximum permissive concentration of the appropriate metal salt. RNA was extracted using a Qiagen RNeasy kit according to the manufacturer's instructions. cDNA probes were generated as described by Sigma-Genosys, using primers and reverse transcriptase provided. Hybridized probes were visualized by autoradiography using a phosphorimager (Bio-Rad, Personal FX). Hybridization intensity was quantified and compared using Quantity One (Bio-Rad) and Excel (Microsoft). Transcriptional profiles for each strain of cells were compared to that of the wild-type strain grown to stationary phase in the absence of metal ions. LB medium was used to allow future array experiments involving alternative challenges to be comparable with this data set.

Amplification of the insA-7 coding region and plasmid construction. All DNA manipulations were carried out according to Sambrook et al. (1989). The ins A-7 coding region was amplified from the $\mathrm{Co}(\mathrm{II})$-tolerant strain ECo using primers A7(V)N-term (5'-CGGAATTCTGCGTGGCTTCCATTTCCATCAGATGTCC-3') and A7C-term (5'-GCTCTAGACGCTGACGTGATTTAGCACCGACG-3') (synthesized by Gibco-BRL). The nucleotide sequence of the amplified ins $A$ was determined and was identical to that reported, except for one base change ( +150 from start codon: $\mathrm{C}$ to $\mathrm{A})$. This change does not affect the primary amino acid sequence. The derivative of pBAD24 (Guzman et al., 1995) carrying the ins A-7 coding region was created by digesting the PCR product with EcoRI and $\mathrm{XbaI}$ and ligating together with identically cut pBAD24 to generate pBADinsA-7.

insA-7 expression. Overnight cultures of TG2(pBAD24) or TG2(pBADins A-7) were used to inoculate $20 \mathrm{ml}$ fresh LB medium containing arabinose at a final concentration of $0.5 \%$ $(\mathrm{w} / \mathrm{v})$. A $200 \mu \mathrm{l}$ sample of each culture was transferred into separate wells of a microtitre plate containing increasing concentration ranges of $\mathrm{Zn}(\mathrm{II}), \mathrm{Cd}(\mathrm{II}), \mathrm{Co}(\mathrm{II})$ or $\mathrm{Ni}(\mathrm{II})$. The cultures were incubated at $37^{\circ} \mathrm{C}$ with shaking, and the $\mathrm{OD}_{600}$ was measured (Molecular Devices Thermo max microplate reader) every 1 or $2 \mathrm{~h}$ over a $30 \mathrm{~h}$ period. Carbenicillin was added to medium to allow selection of pBAD24 and pBADins A-7 which carry the bla marker gene.

\section{RESULTS AND DISCUSSION}

\section{Adaptation of $E$. coli to metal tolerance}

E. coli TG1 was grown in LB medium supplemented with a range of either $\mathrm{Zn}(\mathrm{II}), \mathrm{Cd}(\mathrm{II}), \mathrm{Co}(\mathrm{II})$ or $\mathrm{Ni}(\mathrm{II})$ and the MICs were determined as $2 \cdot 2,1 \cdot 2,1.7$ and $4.0 \mathrm{mM}$, respectively (Fig. 1). The MIC values for the four metal ions were also determined for derivative strains individually adapted for growth in elevated concentrations of $\mathrm{Zn}(\mathrm{II})$ (strain EZn), Cd(II) (strain ECd), Co(II) (strain $E \mathrm{Co}$ ) and $\mathrm{Ni}(\mathrm{II})$ (strain ENi). Despite the diminished solubility of metal ions in a rich medium, a clear increase in tolerance was observed for all the adapted strains. EZn was tolerant to $\mathrm{Zn}$ (II) at $9.0 \mathrm{mM}$ (Fig. 1) and also exhibited slight cross-tolerance to $\mathrm{Co}$ (II) and $\mathrm{Ni}$ (II) but sensitivity to $\mathrm{Cd}$ (II) (data not shown). ECd exhibited an MIC to Cd(II) of $4.0 \mathrm{mM}$ (Fig. 1) and this strain showed increased tolerance to $\mathrm{Co}(\mathrm{II})$ and $\mathrm{Ni}(\mathrm{II})$ (data not shown). ECo is dramatically increased in tolerance, exhibiting growth at over $23.0 \mathrm{mM}$ supplementary $\mathrm{Co}$ (II) (Fig. 1) and showing an increase in tolerance to $\mathrm{Ni}(\mathrm{II})$ (data not shown). The MIC of ENi was $19.0 \mathrm{mM}$ (Fig. 1) and significant cross-tolerance to $\mathrm{Co}(\mathrm{II})$ was observed with an increase in sensitivity to $\mathrm{Cd}(\mathrm{II})$ (data not shown). That metal-ion cross-tolerance/dependence was observed is unsurprising given the chemical similarities that exist between these divalent cations.

\section{Transcriptional analysis of adapted strains}

Transcriptional profiles were generated using macroarrays (Sigma-Genosys) representing all 4255 ORFs present in the E. coli genome (Blattner et al., 1997). The genes of interest which were significantly modulated (more than two standard deviations from the mean) are detailed (Tables 1 and 2). For brevity, not all significant results are shown here (complete listings can be accessed via URL http://www.cf.ac.uk/biosi/staff/people/ morby.html).

Analysis of genes for which transcriptional levels are decreased (Table 1 ) reveals a significant commonality. Of those with a known function, $y f i A$ (translational stimulator; Bylund et al., 1997), tufA/tufB (EF-Tu; reviewed by Weijland et al., 1992) and yjbC (putative pseudouridylate synthase, shows similarity to $r s u A$; Wrzesinski et al., 1995) encode proteins involved in translation; this adaptation may comprise a general response to stress or may merely be a function of lower growth rates in the presence of a toxic agent. In addition, tnaA (tryptophanase; Deeley \& Yanofsky, 1981) and aspA (aspartase; Guest et al., 1984) are reduced, suggesting the cell is less catabolic in nature.

Consistent with tolerance to cations, ompC and ompA, which encode outer-membrane porins (Ried et al., 1990), are reduced in most of the adapted strains. b0795, which shows similarity to $\mathrm{CzcB}$ (a component of a cation efflux pump; Nies et al., 1989), is reduced in all four strains. Analysis of the b0795-encoded sequence shows the presence of a signal peptide, suggesting it is periplasmic in location. In addition, the operon which contains 

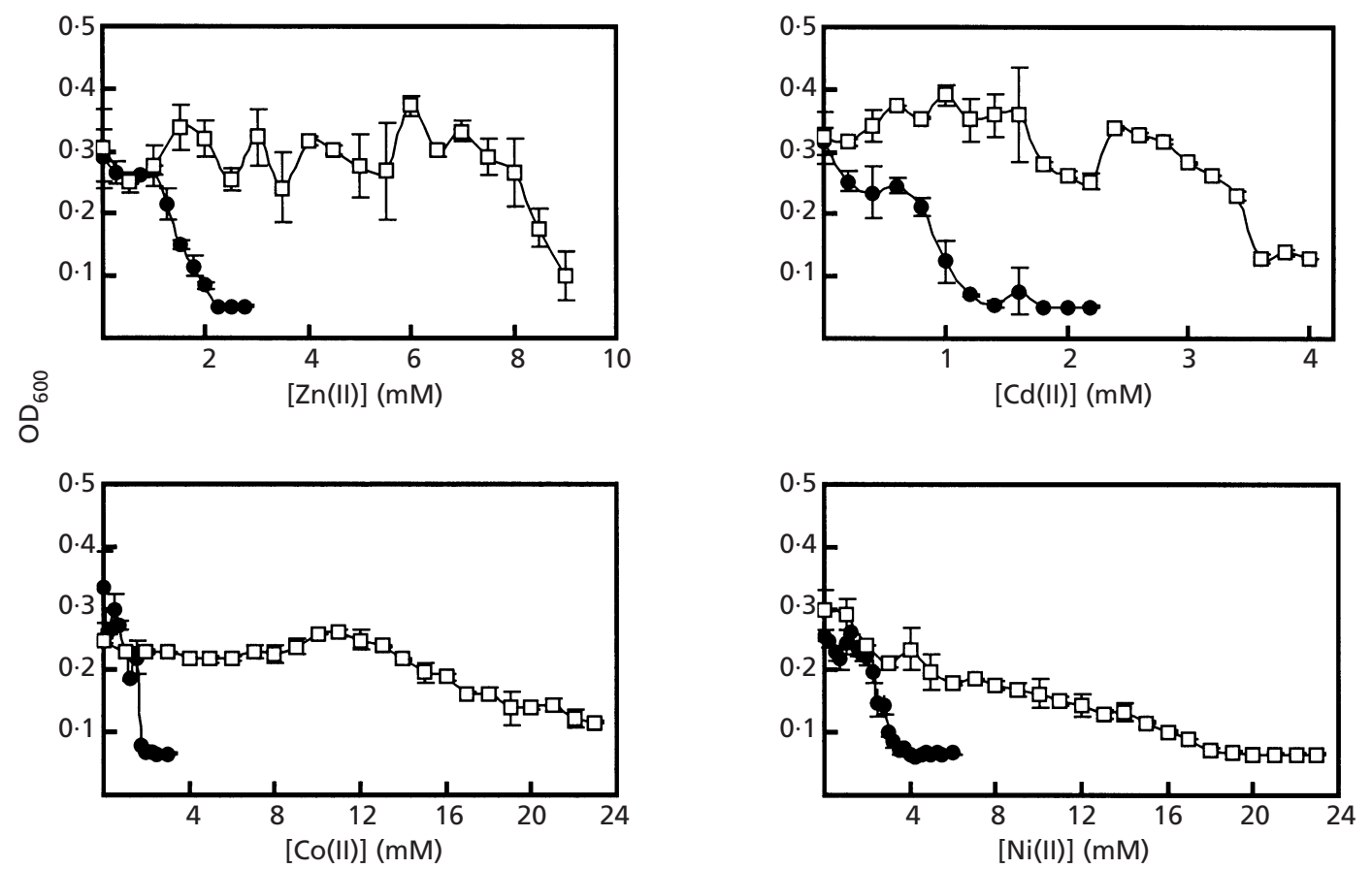

Fig. 1. Liquid MICs for $\mathrm{Zn}(\mathrm{II}), \mathrm{Cd}(\mathrm{II}), \mathrm{Co}(\mathrm{II})$ and $\mathrm{Ni}(\mathrm{II})$, shown for $E$. coli TG1 adapted for tolerance to $\mathrm{Zn}$ (II) (strain EZn), $\mathrm{Cd}(\mathrm{II})$ (strain $E C \mathrm{Cd}$ ), $\mathrm{Co}(\mathrm{II})$ (strain $E \mathrm{Co}$ ) and $\mathrm{Ni}(\mathrm{II})$ (strain $E \mathrm{Ni}$ ), respectively. The $\mathrm{OD}_{600}$ was determined for each strain ( $\square$ ); wild-type $E$. coli TG1 is shown on each graph as a comparison (-). The graphs show $\mathrm{OD}_{600}$ against metal-ion concentration. Assays were performed in triplicate and the SDS are shown.

Table 1. Transcriptional profiles of metal-ion-tolerant strains: genes of interest for which transcriptional levels were decreased are listed

The fold decrease in transcript abundance is shown for each gene in each strain where appropriate.

\begin{tabular}{|c|c|c|c|c|c|}
\hline \multirow[t]{2}{*}{ Gene } & \multirow[t]{2}{*}{ Gene product description } & \multicolumn{4}{|c|}{ Fold decrease in strain: } \\
\hline & & EZn & ECd & ECo & $\mathrm{ENi}$ \\
\hline$y f i A$ & Putative translational stimulator & $9 \cdot 7$ & $16 \cdot 2$ & $11 \cdot 4$ & $15 \cdot 0$ \\
\hline $\operatorname{tna} A$ & Tryptophanase & $9 \cdot 2$ & $15 \cdot 4$ & $9 \cdot 8$ & $15 \cdot 3$ \\
\hline $\operatorname{tufB}$ & Elongation factor EF-Tu (duplicate gene) & $7 \cdot 3$ & $11 \cdot 4$ & $12 \cdot 0$ & $11 \cdot 5$ \\
\hline$y j b C$ & Putative pseudouridylate synthase & $5 \cdot 6$ & $5 \cdot 0$ & $10 \cdot 2$ & $10 \cdot 4$ \\
\hline $\operatorname{asp} A$ & Aspartase & $4 \cdot 0$ & $8 \cdot 8$ & $7 \cdot 9$ & $7 \cdot 7$ \\
\hline tufA & Protein chain elongation factor EF-Tu (duplicate of $t u f B$ ) & $3 \cdot 4$ & $5 \cdot 5$ & $8 \cdot 9$ & $12 \cdot 1$ \\
\hline b0795 (f332) & Putative periplasmic protein, sequence similarity to $c z c B$ & $6 \cdot 7$ & $4 \cdot 5$ & $6 \cdot 9$ & $7 \cdot 0$ \\
\hline ompC & Outer-membrane protein $\mathrm{C}$ precursor & $5 \cdot 4$ & $6 \cdot 4$ & $4 \cdot 8$ & 3.9 \\
\hline$o m p A$ & Outer-membrane protein A & $5 \cdot 0$ & $3 \cdot 5$ & & $5 \cdot 8$ \\
\hline
\end{tabular}

b0795 also contains genes whose products are similar to ABC-transporter proteins. It is possible that this operon is involved in cation import and therefore it is consistent for one or more components to be diminished in metaladapted cells.

Genes which show increased transcriptional levels (Table 2) also have some commonality between strains. Some induced genes have a functional association with metal cations, including nikD $[\mathrm{Ni}(\mathrm{II})$ export; Navarro et al., 1993], yfeC [putative chelated-Fe(II) export; Bearden et al., 1998], yeaJ (shows sequence similarity to $h m s T$, a putative regulator of haem storage; Jones et al., 1999) and bis C (biotin sulfoxide reductase, binds molybdenum; Pierson \& Campbell, 1990). These gene products could be involved in the chelation of excess cytosolic metal ions which may generate tolerance or perhaps represent compensatory alterations which preserve cation [e.g. $\mathrm{Mn}(\mathrm{II})$ or $\mathrm{Fe}(\mathrm{II})$ ] metabolism in the presence of excess $\mathrm{Zn}(\mathrm{II}), \mathrm{Cd}(\mathrm{II}), \mathrm{Co}(\mathrm{II})$ or $\mathrm{Ni}(\mathrm{II})$.

The majority of the characterized genes identified in this 
Table 2. Transcriptional profiles of metal-ion-tolerant strains: genes of interest for which transcriptional levels were increased are listed

The fold increase in transcript abundance is shown for each gene in each strain where appropriate.

\begin{tabular}{|c|c|c|c|c|c|}
\hline \multirow[t]{2}{*}{ Gene } & \multirow[t]{2}{*}{ Gene product description } & \multicolumn{4}{|c|}{ Fold increase in strain: } \\
\hline & & EZn & ECd & ECo & $E N i$ \\
\hline ins A-7 & Insertion element IS1 protein InsA & $3 \cdot 5$ & $3 \cdot 8$ & $2 \cdot 2$ & \\
\hline ins A-6 & Insertion element IS1 protein InsA & $3 \cdot 5$ & $3 \cdot 4$ & $3 \cdot 8$ & \\
\hline ins $A-1$ & Insertion element IS1 protein InsA & & $3 \cdot 3$ & $3 \cdot 6$ & \\
\hline ins $A-2$ & Insertion element IS1 protein InsA & $3 \cdot 3$ & & $3 \cdot 0$ & \\
\hline ins $A-5$ & Insertion element IS1 protein InsA & $4 \cdot 0$ & $6 \cdot 6$ & & \\
\hline ins $B-1$ & Insertion element IS1 protein InsB & $2 \cdot 6$ & & $4 \cdot 2$ & \\
\hline ins $B-6$ & Insertion element IS1 protein InsB & $2 \cdot 8$ & & $3 \cdot 1$ & \\
\hline$n i k D$ & Nickel transport ATP-binding protein NikD & $8 \cdot 2$ & $21 \cdot 5$ & & \\
\hline$y f e C$ & Putative chelated $\mathrm{Fe}(\mathrm{II})$-export protein & $8 \cdot 0$ & $20 \cdot 1$ & & \\
\hline bis $C$ & Biotin sulfoxide reductase & & & $3 \cdot 1$ & $2 \cdot 9$ \\
\hline yeaJ & Putative haem storage regulator & $3 \cdot 1$ & & $4 \cdot 3$ & \\
\hline
\end{tabular}

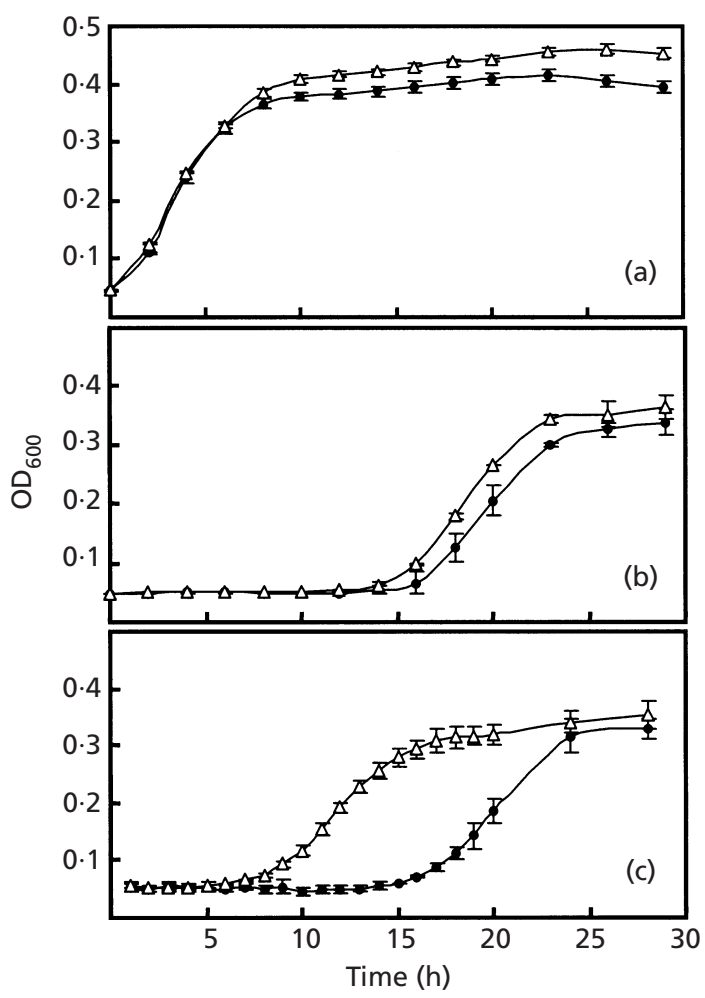

Fig. 2. Graphs showing growth curves for TG2(pBAD24) (0) and TG2(pBADinsA-7) $(\triangle)$. (a) Growth medium containing no additional metal ions. (b) Growth medium containing $0.6 \mathrm{mM}$ $\mathrm{Cd}$ (II). (c) Growth medium containing $1.0 \mathrm{mM} \mathrm{Zn}$ (II). The graphs show $\mathrm{OD}_{600}$ against time. Assays were performed in triplicate and the SDs are shown.

experiment encode proteins involved in the transposition of IS1, 2, 3, 5 and 30 (see data at URL http://www.cf.ac.uk/biosi/staff/people/morby.html).
It is well documented that IS genes may be induced by cellular stress and it is hypothesized that the movement of IS elements is capable of increasing genetic diversity (Naas et al., 1994).

The most consistently induced genes are those for ins A (IS1 transposition), for which transcripts are elevated in three out of the four strains. It is impossible to determine from array analyses which of the ins $A / B$ sequences were induced, given the close sequence similarity within the gene families, which may have resulted in crosshybridization during the experiment. The repeated increase in transcript abundance of ins $A$ genes led to the investigation of metal tolerance in a wild-type strain expressing ins A-7 from a heterologous promoter.

\section{Increase in metal tolerance by overexpression of insA-7}

E. coli TG2 carrying pBADinsA-7 was generated in which gene expression was controlled by the level of arabinose in the medium. ins A-7 was used since all ins $A$ sequences are almost identical and this gene has no apparent associated ins $B$. When grown in medium containing arabinose, but no additional metal ions, TG2(pBADins A-7) showed a slight growth advantage over TG2(pBAD24) (Fig. 2a). In contrast, when grown in the presence of arabinose plus $0.6 \mathrm{mM} \mathrm{Cd}(\mathrm{II})$ and $1.0 \mathrm{mM} \mathrm{Zn(II),} \mathrm{TG2(pBADinsA-7)} \mathrm{shows} \mathrm{a} \mathrm{slight} \mathrm{in-}$ crease in tolerance to $\mathrm{Cd}(\mathrm{II})$ but a marked increase in tolerance to $\mathrm{Zn}$ (II) (Fig. 2b, c). No increase in tolerance to $\mathrm{Co}(\mathrm{II})$ or $\mathrm{Ni}(\mathrm{II})$ was observed (data not shown). The ins $A$-dependent increase in tolerance to $\mathrm{Zn}(\mathrm{II})$ is consistent with the observation that EZn showed increases in transcript abundance for genes encoded by IS1.

InsA alone binds to pinsL to negatively auto-regulate and inhibit transposition of IS1 (Zerbib et al., 1987; Machida \& Machida, 1989; Matsutani, 1997). The 
heterologous expression of ins A-7 should therefore reduce transposition of IS1 in TG2 (pBADins A-7), which suggests that the metal-tolerance phenotype is directly conferred by an increase of InsA-7 within the cell. This result contradicts the dogma that IS elements cannot directly enhance the fitness of their host, but merely carry genes for transposition functions (Blot et al., 1993). Analysis of the InsA-7 primary sequence shows the presence of two cysteine-X-X-cysteine motifs which are known to bind metal ions in both prokaryotic and eukaryotic proteins containing HMA motifs (GXXCXXC) (Bull \& Cox, 1994); such motifs also occur in group I, II and III metallothioneins (reviewed by Kille et al., 1994). The CXXC motifs in InsA-7 may enable this protein to bind metal ions in the cell cytosol. Given the spacing between the two CXXC motifs it is possible that these proteins bind to DNA using a $\mathrm{Zn}$ (II)-finger motif rather than the helix-turn-helix motif previously identified by weak similarity ( $24 \%$ identity) to known helix-turn-helix motifs (Zerbib et al. 1987).

\section{Concluding remarks}

In response to toxic concentrations of $\mathrm{Zn}(\mathrm{II}), \mathrm{Cd}(\mathrm{II})$, $\mathrm{Co}(\mathrm{II})$ or $\mathrm{Ni}(\mathrm{II})$, E. coli exhibited varying degrees of tolerance (3-14-fold greater than wild-type) both to the adaptive metal and its congeners. All of the adapted strains showed similar patterns of diminished gene expression, with particular bias towards genes whose products are involved in translation. No single gene whose expression increased was common to the four adapted strains, but surprisingly ins $A$ was increased in the $\mathrm{Zn}(\mathrm{II})-$, $\mathrm{Cd}(\mathrm{II})$ - and $\mathrm{Co}(\mathrm{II})$-adapted strains. Subsequent expression of ins A-7 in E. coli demonstrated that this gene can confer tolerance to $\mathrm{Zn}(\mathrm{II})$, suggesting that it may be capable of binding divalent metal ions by virtue of two paired cysteine motifs. This study shows the utility of an array-based approach to functional genomics in E. coli and the capacity for the generation of novel avenues of research using these techniques.

\section{ACKNOWLEDGEMENTS}

We thank Mr S. Megit for technical assistance and moral support, and Dr Colin Berry for constructive criticism of this manuscript. We acknowledge the support of BBSRC grant G09282 awarded to A.P.M.

\section{REFERENCES}

Bearden, S. W., Staggs, T. M. \& Perry, R. D. (1998). An ABC transporter system of Yersinia pestis allows utilization of chelated iron by Escherichia coli SAB11. J Bacteriol 180, 1135-1147.

Blattner, F. R., Plunkett, G., III, Bloch, C. A. \& 14 other authors (1997). The complete genome sequence of Escherichia coli K-12. Science 277, 1453-1474.

Blot, M., Heitman, J. \& Arber, W. (1993). Tn5-mediated bleomycin resistance in Escherichia coli requires the expression of host genes. Mol Microbiol 8, 1017-1024.

Bull, P. C. \& Cox, D. W. (1994). Wilson disease and Menkes disease: new handles on heavy-metal transport. Trends Genet $\mathbf{1 0}$, 246-252.
Bylund, G. O., Persson, B. C., Lundberg, L. A. C. \& Wikstrom, P. M. (1997). A novel ribosome-associated protein is important for efficient translation in Escherichia coli. J Bacteriol 179, 4567-4574.

Deeley, M. C. \& Yanofsky, C. (1981). Nucleotide-sequence of the structural gene for tryptophanase of Escherichia coli K-12. J Bacteriol 147, 787-796.

Giller, K. E., Witter, E. \& McGrath, S. P. (1998). Toxicity of heavy metals to microorganisms and microbial processes in agricultural soils: a review. Soil Biol Biochem 30, 1389-1414.

Guest, J. R., Roberts, R. E. \& Wilde, R. J. (1984). Cloning of the aspartase gene (aspA) of Escherichia coli. J Gen Microbiol 130, 1271-1278.

Gupta, A., Whitton, B. A., Morby, A. P., Huckle, J. W. \& Robinson, N. J. (1992). Amplification and rearrangement of a prokaryotic metallothionein locus smt in Synechococcus PCC-6301 selected for tolerance to cadmium. Proc R Soc Lond Ser B Biol Sci 248, 273-281.

Gupta, A., Morby, A. P., Turner, J. S., Whitton, B. A. \& Robinson, N. J. (1993). Deletion within the metallothionein locus of cadmium-tolerant Synechococcus PCC-6301 involving a highly iterated palindrome (hip1). Mol Microbiol 7, 189-195.

Guzman, L. M., Belin, D., Carson, M. J. \& Beckwith, J. (1995). Tight regulation, modulation, and high-level expression by vectors containing the arabinose P-Bad promoter. J Bacteriol 177, 4121-4130.

Jones, H. A., Lillard, J. W. \& Perry, R. D. (1999). HmsT, a protein essential for the expression of the haemin storage $\left(\mathrm{hms}^{+}\right)$system of Yersinia pestis. Microbiology 145, 2117-2128.

Kelly, J. J., Haggblom, M. \& Tate, R. L. (1999). Changes in soil microbial communities over time resulting from one time application of zinc: a laboratory microcosm study. Soil Biol Biochem 31, 1455-1456.

Kille, P., Hemmings, A. \& Lunney, E. A. (1994). Memories of metallothionein. Biochim Biophys Acta 1205, 151-161.

Machida, C. \& Machida, Y. (1989). Regulation of IS1 transposition by the ins A gene-product. J Mol Biol 208, 567-574.

Matsutani, S. (1997). Genetic analyses of the interactions of the IS1-encoded proteins with the left end of IS1 and its insertion hotspot. J Mol Biol 267, 548-560.

Naas, T., Blot, M., Fitch, W. M. \& Arber, W. (1994). Insertion sequence-related genetic-variation in resting Escherichia coli $\mathrm{K}$ 12. Genetics 136, 721-730.

Navarro, C., Wu, L. F. \& Mandrand-Berthelot, M. A. (1993). The nik operon of Escherichia coli encodes a periplasmic bindingprotein-dependent transport system for nickel. Mol Microbiol 9, 1181-1191.

Nies, D. H. (1999). Microbial heavy-metal resistance. Appl Microbiol Biotechnol 51, 730-750.

Nies, D. H., Nies, A., Chu, L. \& Silver, S. (1989). Expression and nucleotide sequence of a plasmid-determined divalent cation efflux system from Alcaligenes eutrophus. Proc Natl Acad Sci USA 86, 7351-7355.

Pierson, D. E. \& Campbell, A. (1990). Cloning and nucleotide sequence of bis $C$, the structural gene for biotin sulfoxide reductase in Escherichia coli. J Bacteriol 172, 2194-2198.

Ried, G., Hindennach, I. \& Henning, U. (1990). Role of lipopolysaccharide in assembly of Escherichia coli outer membrane proteins OmpA, OmpC, and OmpF. J Bacteriol 172, 6048-6053. Sambrook, J., Fritsch, E. F. \& Maniatis, T. (1989). Molecular 
Cloning: a Laboratory Manual, 2nd edn. Cold Spring Harbor, NY: Cold Spring Harbor Laboratory.

Weijland, A., Harmark, K., Cool, R. H., Anborgh, P. H. \& Parmeggiani, A. (1992). Elongation factor TU: a molecular switch in protein biosynthesis. Mol Microbiol 6, 683-688.

Wrzesinski, J., Bakin, A., Nurse, K., Lane, B. G. \& Ofengand, J. (1995). Purification, cloning, and properties of the 16S RNA pseudouridine 516 synthase from Escherichia coli. Biochemistry 34, 8904-8913.
Xu, C., Zhou, T. Q., Kuroda, M. \& Rosen, B. P. (1998). Metalloid resistance mechanisms in prokaryotes. J Biochem 123, 16-23.

Zerbib, D., Jakowec, M., Prentki, P., Galas, D. J. \& Chandler, M. (1987). Expression of proteins essential for IS1 transpositionspecific binding of ins A to the ends of IS1. EMBO $J \mathbf{6}$, 3163-3169.

Received 2 March 2000; revised 15 May 2000; accepted 15 June 2000. 